\title{
Use of blubber fatty acid profiles to detect inter-annual variations in the diet of grey seals Halichoerus grypus
}

\author{
Michael Walton*, Patrick Pomeroy \\ Sea Mammal Research Unit, University of St Andrews, East Sands, St Andrews KY16 8LB, United Kingdom
}

\begin{abstract}
Diet, and how it varies in place and time, are important factors in understanding the interactions between seals and fisheries. The grey seal eats a wide variety of prey species and variations in availability of prey can lead to changes in both foraging behaviour and diet that could affect the ecological impact of the seals. Since it is difficult to observe the feeding behaviour of seals directly, we have used changes in the fatty acid profiles of blubber to indicate changes in their diet. We studied inter-colony and inter-annual variations in the fatty acid profiles of female seals from 2 Scottish breeding colonies, North Rona (RON) and the Isle of May, over 3 consecutive years from 1996 to 1998 . The fatty acid profiles obtained were compared and tested using several multivariate statistical methods, including a new inter-population measure Dfap (a distance measure based on fatty acid profiles). There were significant inter-colony differences in blubber fatty acids in all years of the study. There were significant within-colony variations among years for the seals at the Isle of May but not at RON. Individual seals sampled in more than $1 \mathrm{yr}$ tended to change in a similar manner at the Isle of May but not at RON. Discriminant analysis of the fatty acid profiles provided classifications of the Isle of May seals according to year with 84 to $97 \%$ accuracy, but was less successful with the RON seals with 56 to $74 \%$ accuracy. Only 4 out of 166 seals were 'mis-classified' into the wrong Isle of May or RON grouping. This analysis suggested a shift in diet at the Isle of May that was supported by evidence from a separate study on the analysis of otoliths in seal faeces.
\end{abstract}

KEY WORDS: Fatty acids · Grey seals · Diet $\cdot$ Blubber

\section{INTRODUCTION}

Knowledge of the diet of marine mammals such as the grey seal Halichoerus grypus is directly relevant for understanding trophic interactions and for formulating management policies in such matters as conflicts with the fishing industry (Harwood 1987, Harwood \& Croxall 1988, Tollitt \& Thompson 1996, Brown et al. 2000). Because of the difficulties in directly observing the feeding behaviour of grey seals, a number of indirect techniques have been used to gain necessary information. The analysis of prey remains (otoliths, bone fragments etc.) in faecal samples is a much favoured technique which has the advantages of being relatively cheap, non-invasive as well as providing both identification and quantification of the prey species eaten. It is, however, subject to a number of biases (Jobling \& Breiby 1986, Jobling 1987, Pierce et al. 1990, 1991, 1993) which have been discussed by Iverson (1993), who has proposed the use of blubber fatty acid profiles as a means of overcoming these biases. It is the aim of Iverson and colleagues (Iverson 1993, Smith et al. 1997, 1999, Kirsch et al. 2000) to be able to produce, from a knowledge of the fatty acid profiles of seals and their prey, a quantitative estimate of the components of the seal's diet. They are currently in the process of developing a statistical model to achieve such an analysis. However, there has been some criticism concerning the viability and practicality of such a model (see comments by Grahl-Nielsen 1999 and response by Smith et al. 1999). Thus, in the absence of such a model which can provide quantita- 
tive data, fatty acid profile studies have been used in a qualitative manner for such purposes as identifying stocks of several species (Grahl-Nielsen et al. 1993, Castell et al. 1995, Smith et al. 1996, Iverson et al. 1997b) or detecting dietary differences (Ackman et al. 1971, West et al. 1979, Grahl-Nielsen et al. 1993, Kakela et al. 1993, Castell et al. 1995, Pond et al. 1995, Walton et al. 2000).

There is, however, little information on how fatty acid profiles change in individuals over time. In a previous study, we showed (Walton et al. 2000) that grey seals from the 2 Scottish breeding colonies sampled in 1996 could be differentiated based on their fatty acid profiles, implying that seals from the 2 colonies had eaten substantially different diets contemporaneously and hence, could be regarded as separate ecological as well as genetic stocks. That study has now been extended to answer some questions related to changes over time: (1) Can the difference between colonies found in 1996 be detected in other years? (2) How do the profiles vary from year to year at the same site? (3) How does the profile of individual seals vary from year to year? To answer these questions, seals were studied at 2 breeding sites: the islands of North Rona (RON) and Isle of May (MAY). During the course of other studies (see Pomeroy et al. 1999), a number of females have been individually identified and the reproductive success of individual females followed over the course of many years. Thus, the breeding period provides a good opportunity to sample relatively large numbers of seals, and particularly, to sample the same seal in a longitudinal time series. Throughout the rest of the year the seals are much more difficult to catch and sample.

In this study, we looked at between-site and withinsite differences in fatty acid profiles over the course of 3 breeding seasons (1996, 1997 and 1998). Results were analysed and compared using a variety of multivariate techniques. For the Isle of May seals, it was also possible to compare the results with dietary data obtained from a separate study using faecal analysis techniques.

\section{MATERIALS AND METHODS}

Tissue collection. Female seals were captured and immobilised (see Pomeroy et al. 1999 for details) at the breeding sites of $\mathrm{RON}\left(59^{\circ} 06^{\prime} \mathrm{N}, 5^{\circ} 50^{\prime} \mathrm{W}\right)$ and MAY $\left(56^{\circ} 10^{\prime} \mathrm{N}, 2^{\circ} 33^{\prime} \mathrm{W}\right)$ (see Walton et al. 2000 for a map). After making a small cut with a disposable scalpel, a blubber sample of about $0.5 \mathrm{~g}$ was collected from the mid-pelvic region using a $6 \mathrm{~mm}$ diameter disposable, single-use biopsy needle (Acuderm). All biopsy samples were comprised of a complete cross-section of
Table 1. Halichoerus grypus. Number of female grey seals sampled. North Rona (RON) and the Isle of May (MAY)

\begin{tabular}{|lcc|}
\hline \multirow{2}{*}{ Year(s) } & \multicolumn{2}{c|}{ Breeding site } \\
& RON & MAY \\
\hline All females & & \\
1996 & 23 & 34 \\
1997 & 25 & 31 \\
1998 & 25 & 28 \\
Individually marked females sampled in more than $\mathbf{1}$ yr \\
1996 and 1997 & 16 & 16 \\
1997 and 1998 & 9 & 19 \\
1996 and 1998 & 12 & 16 \\
1996,1997 and 1998 & 8 & 12 \\
& & \\
\hline
\end{tabular}

blubber from the junctions of the skin and muscle, and were taken soon after the start of the lactation period. Samples were stored in chloroform:methanol (2:1, vol:vol) containing $0.05 \%$ butylated hydroxytoluene (BHT) as antioxidant until being returned to the laboratory where it was possible to store them at $-20^{\circ} \mathrm{C}$ until analysis a few weeks later (Iverson et al. 1997b). The number of samples collected at each colony during the breeding seasons of 1996, 1997 and 1998 is shown in Table 1, which also lists the number of individually marked females that were caught and sampled in more than 1 yr. All procedures were performed under the appropriate guidelines, as described in Governmental Project Licences and by ASAB (Association of Animal Behaviour), for handling animals.

Lipid extraction, fatty acid methylation and purification. Total lipid was extracted (Folch et al. 1957) from the blubber and fatty acid methyl esters prepared as described previously (Walton et al. 2000), and then dissolved in hexane $\left(10 \mathrm{mg} \mathrm{ml}^{-1}\right)$.

Gas chromatography analysis. Fatty acid methyl esters (FAME) were analysed by gas-liquid chromatography on a Trace GC-2000 gas chromatograph (Thermoquest, CE Instruments) equipped with a flame-ionization detector and fitted with a BPX70 fused silica capillary column $(30 \mathrm{~m} \times 0.25 \mathrm{~mm}$ internal diameter, S. G. E. Ltd.). Hydrogen was employed as the carrier gas and sample application was by split injection. The temperature of the oven was programmed to start at $60^{\circ} \mathrm{C}$ and held at $60^{\circ} \mathrm{C}$ for 2 min, then to rise to $150^{\circ} \mathrm{C}$ at $20^{\circ} \mathrm{C} \mathrm{min}{ }^{-1}$, held for $2 \mathrm{~min}$ and then to rise to $205^{\circ} \mathrm{C}$ at $1.8^{\circ} \mathrm{C} \mathrm{min}^{-1}$ and finally rising to $230^{\circ} \mathrm{C}$ at $5^{\circ} \mathrm{C} \mathrm{min}^{-1}$. Separated components were identified by reference to authentic standards, ECL values, and fractionation of seal samples by silver-nitrate chromatography (Christie 1989) and by comparisons with samples run at other laboratories.

In this study, 57 individual fatty acids were assayed and are expressed as the percentage by weight of the 
total fatty acids characterised. Results based on 33 fatty acids have already been presented for the samples collected during 1996 (Walton et al. 2000). These samples were reanalysed at the same time as the other samples so that for comparative purposes, all samples were run on the same column, under the same conditions for the same number of fatty acids. As is customary, values are quoted to 2 decimal places; however, this is for comparison purposes and this degree of accuracy is not implied (see Ackman et al. 1971).

Statistical treatment of results. The fatty acid profiles were compared for variations between sites for each study year and also between years for both RON and MAY seals using both univariate and multivariate statistical procedures (SYSTAT Version 9 for Windows). The 3 main multivariate approaches used were principal components analysis (PCA), discriminant analysis and classification TREE analysis, the uses of which were described previously (Walton et al. 2000).

A quantitative measure of the average interpopulation difference between fatty acid profiles was obtained with the measure we have called Dfap (fap = fatty acid profile). This is an analogue of Gst (Palumbi et al. 1991) or the Phist measures of AMOVA (analysis of molecular variance, Excoffier et al. 1992) which are normally applied to studies of variation in DNA sequences. Dfap was calculated using the AMOVA program but using a matrix of fatty acid profile distances rather than one of DNA sequence differences. The fatty acid distance matrix was prepared with the QSK procedure with SYSTAT and then exported to the computer package ARLEQUIN (Schneider et al. 1996) which contains the AMOVA procedure. Apart from using a distance measure based on fatty acid profiles rather than DNA sequences, the procedure is similar. (Note however that since fatty acid profiles are not genetically determined, the additional calculations performed by AMOVA relating to gene flow and coancestry should be ignored.) As with Phist, Dfap is effectively a measure of the variance in the data due to interpopulation differences, corrected for withinpopulation differences. The inter-population distance measure Dfap can theoretically take a value of between 0 and 1, and represents the proportion of the total variance in the data due to inter-population differences. In reality, at least with DNA studies, the theoretical maximum of 1 is rarely approached and values of $>0.15$ may be considered as showing great genetic differentiation (Wright 1978). The statistical significance of the calculated Dfap value can be tested by bootstrap analysis (Monte Carlo resampling) of the data set which is an option available in the AMOVA program.

\section{RESULTS}

\section{Fatty acid composition}

The mean fatty acid profiles plus summarised totals of various classes of fatty acid for each of the 6 colony year groupings are shown in Table 2. Fifty-seven different fatty acids were quantified and used in the statistical analyses, but only those fatty acids which contributed more than $0.5 \%$ to the total are shown individually in this table. A copy of the full table is available on request from the authors. Although some differences can be seen, the 6 profiles are broadly similar with 9 fatty acids $(18: 1 \mathrm{n}-9,22: 6 \mathrm{n}-3,16: 1 \mathrm{n}-7$, 16:0, 20:1n-9, 20:5n-3, 14:0, 18:1n-11 and 22:5n-3 listed in order of decreasing significance) contributing about $75 \%(74.1$ to $77.2 \%)$ of the total mass present. Approximately $1 / 2$ of the total mass was due to monounsaturated and $1 / 3$ due to polyunsaturated fatty acids. As commonly found in marine lipids, the samples were rich in (n-3) compared to (n-6) fatty acids; the ratios of $(n-3):(n-6)$ ranged from 7.0 to 10.2. ANOVA analyses were not performed on individual fatty acids but were performed on of the sums of various fatty acid class groupings. Of these, only the sum of (n-6) fatty acids showed significant differences between means of the MAY samples compared to the RON samples (results not shown).

\section{Dfap and other measures based on fatty acid distances}

The Dfap values are shown in Table 3. In all cases, as is also the case in DNA studies, most of the variation occurred within populations rather than between populations. The comparisons between RON and MAY produced values from 0.109 to 0.225 , indicating that of the total variance in the data, the variation due to interpopulation differences ranged from 10.9 to $22.5 \%$. The values for all 3 years are significantly different, but the actual degree of difference was greatest in 1996; the Dfap value being almost twice the values found in 1997 and 1998. The results indicate significant differences in the fatty acid profiles between RON and MAY in all 3 years, suggesting that the diets of seals from these 2 localities were also substantially different, at least over this time period.

At RON, Dfap between years tended to be low $(0.001$ to 0.018 ) and none of these values was found to be statistically significant. In contrast, at MAY, Dfap was much higher ranging from 0.084 to 0.252 and all these differences were statistically significant $(p<0.001)$, even when corrected for making multiple comparisons using the Bonferroni procedure (Rice 1989). 
Table 2. Halichoerus grypus. Fatty acid methyl ester (FAME) profiles of blubber from seals at North Rona (RON) and the Isle of May (MAY) during the breeding seasons of 1996 to 1998. A total of 57 fatty acids were quantified but only those contributing $>0.5 \%$ of the total are shown individually. Sat $=$ saturated fatty acids, Mono $=$ monounsaturated fatty acids, PUFA $=$ polyunsaturated fatty acids, $n-3=n-3$ series of fatty acids, $n-6=n-6$ series of fatty acids, n3:n6 = ratio of n-3 to n- 6 series of fatty acids.

Values are means $\pm \mathrm{SD}$

\begin{tabular}{|c|c|c|c|c|c|c|}
\hline FAME & $\begin{array}{c}\text { RON } \\
1996 \\
(\mathrm{n}=23)\end{array}$ & $\begin{array}{c}\text { RON } \\
1997 \\
(n=25)\end{array}$ & $\begin{array}{c}\text { RON } \\
1998 \\
(n=25)\end{array}$ & $\begin{array}{c}\text { MAY } \\
1996 \\
(n=34)\end{array}$ & $\begin{array}{c}\text { MAY } \\
1997 \\
(\mathrm{n}=31)\end{array}$ & $\begin{array}{c}\text { MAY } \\
1998 \\
(\mathrm{n}=28)\end{array}$ \\
\hline 14 & $4.94 \pm 0.85$ & $5.31 \pm 0.93$ & $5.18 \pm 0.99$ & $4.72 \pm 0.59$ & $4.85 \pm 0.58$ & $4.42 \pm 0.57$ \\
\hline $14: 1 n-5$ & $1.47 \pm 0.27$ & $1.42 \pm 0.36$ & $1.33 \pm 0.29$ & $1.17 \pm 0.25$ & $1.20 \pm 0.23$ & $1.33 \pm 0.20$ \\
\hline 16 & $9.42 \pm 1.22$ & $9.54 \pm 1.48$ & $9.60 \pm 1.17$ & $9.11 \pm 1.16$ & $9.86 \pm 1.35$ & $8.82 \pm 1.08$ \\
\hline 16:1n-11 & $0.66 \pm 0.10$ & $0.68 \pm 0.08$ & $0.64 \pm 0.08$ & $0.58 \pm 0.05$ & $0.61 \pm 0.05$ & $0.58 \pm 0.07$ \\
\hline $16: 1 n-7$ & $12.49 \pm 1.58$ & $11.91 \pm 1.74$ & $11.59 \pm 1.08$ & $10.60 \pm 1.95$ & $11.31 \pm 1.77$ & $12.63 \pm 1.40$ \\
\hline 18 & $1.13 \pm 0.20$ & $1.19 \pm 0.20$ & $1.17 \pm 0.19$ & $1.01 \pm 0.14$ & $1.11 \pm 0.14$ & $1.04 \pm 0.17$ \\
\hline $16: 4 n-1$ & $0.68 \pm 0.28$ & $0.66 \pm 0.26$ & $0.59 \pm 0.27$ & $0.39 \pm 0.18$ & $0.52 \pm 0.18$ & $0.49 \pm 0.26$ \\
\hline $18: 1 n-11$ & $4.74 \pm 0.93$ & $4.63 \pm 0.86$ & $4.62 \pm 0.84$ & $4.63 \pm 0.53$ & $4.12 \pm 0.68$ & $4.26 \pm 0.80$ \\
\hline $18: 1 n-9$ & $15.91 \pm 2.80$ & $15.45 \pm 2.74$ & $14.99 \pm 2.67$ & $16.00 \pm 3.14$ & $15.32 \pm 2.26$ & $16.13 \pm 2.39$ \\
\hline $18: 1 n-7$ & $3.16 \pm 0.73$ & $2.95 \pm 0.63$ & $2.94 \pm 0.67$ & $2.80 \pm 0.50$ & $2.76 \pm 0.51$ & $3.14 \pm 0.74$ \\
\hline $18: 2 n-6$ & $1.53 \pm 0.40$ & $1.61 \pm 0.38$ & $1.54 \pm 0.27$ & $2.81 \pm 0.43$ & $2.44 \pm 0.35$ & $2.21 \pm 0.24$ \\
\hline $18: 3 n-3$ & $0.66 \pm 0.27$ & $0.74 \pm 0.29$ & $0.79 \pm 0.18$ & $1.73 \pm 0.34$ & $1.63 \pm 0.37$ & $1.20 \pm 0.14$ \\
\hline $18: 4 n-3$ & $1.53 \pm 0.55$ & $1.72 \pm 0.46$ & $1.82 \pm 0.41$ & $2.80 \pm 0.66$ & $2.83 \pm 0.67$ & $2.05 \pm 0.29$ \\
\hline 20:1n-11 & $1.71 \pm 0.29$ & $1.74 \pm 0.51$ & $1.76 \pm 0.53$ & $1.72 \pm 0.30$ & $1.49 \pm 0.32$ & $1.52 \pm 0.39$ \\
\hline $20: 1 n-9$ & $5.78 \pm 1.23$ & $6.23 \pm 1.32$ & $6.27 \pm 1.21$ & $8.00 \pm 1.89$ & $6.44 \pm 1.15$ & $5.90 \pm 1.17$ \\
\hline $20: 4 n-6$ & $0.71 \pm 0.20$ & $0.66 \pm 0.19$ & $0.63 \pm 0.12$ & $0.46 \pm 0.11$ & $0.47 \pm 0.13$ & $0.58 \pm 0.15$ \\
\hline $20: 4 n-3$ & $0.72 \pm 0.12$ & $0.77 \pm 0.15$ & $0.78 \pm 0.11$ & $1.01 \pm 0.16$ & $0.96 \pm 0.16$ & $0.85 \pm 0.11$ \\
\hline $22: 1 n-11$ & $2.58 \pm 0.94$ & $2.81 \pm 1.08$ & $3.22 \pm 1.26$ & $3.12 \pm 1.34$ & $2.71 \pm 0.94$ & $2.53 \pm 1.10$ \\
\hline $20: 5 n-3$ & $5.61 \pm 1.04$ & $5.60 \pm 1.18$ & $5.22 \pm 0.91$ & $5.08 \pm 0.91$ & $5.64 \pm 0.82$ & $5.89 \pm 1.14$ \\
\hline $22: 5 n-3$ & $4.57 \pm 0.49$ & $4.58 \pm 0.46$ & $4.68 \pm 0.75$ & $4.27 \pm 0.39$ & $4.45 \pm 0.43$ & $4.91 \pm 0.39$ \\
\hline $22: 6 n-3$ & $13.76 \pm 1.44$ & $13.52 \pm 1.25$ & $14.43 \pm 1.69$ & $11.72 \pm 1.04$ & $12.91 \pm 0.87$ & $13.15 \pm 1.56$ \\
\hline Others & 6.24 & 6.28 & 6.21 & 6.27 & 6.42 & 6.36 \\
\hline \multicolumn{7}{|l|}{ Sum of: } \\
\hline Sat & $16.30 \pm 1.96$ & $16.88 \pm 2.25$ & $16.78 \pm 1.83$ & $15.54 \pm 1.62$ & $16.54 \pm 1.91$ & $14.70 \pm 1.59$ \\
\hline Mono & $50.61 \pm 3.25$ & $49.86 \pm 2.98$ & $49.38 \pm 3.18$ & $51.08 \pm 2.37$ & $48.22 \pm 2.73$ & $50.14 \pm 2.60$ \\
\hline PUFA & $31.99 \pm 2.20$ & $32.20 \pm 1.87$ & $32.77 \pm 2.83$ & $32.44 \pm 1.45$ & $34.14 \pm 1.51$ & $33.95 \pm 2.18$ \\
\hline$n-3$ & $27.53 \pm 2.01$ & $27.64 \pm 1.66$ & $28.43 \pm 2.61$ & $27.38 \pm 1.27$ & $29.20 \pm 1.36$ & $29.20 \pm 2.15$ \\
\hline$n-6$ & $2.86 \pm 0.30$ & $2.88 \pm 0.31$ & $2.78 \pm 0.27$ & $3.89 \pm 0.31$ & $3.48 \pm 0.30$ & $3.23 \pm 0.29$ \\
\hline n3:n6 & $9.75 \pm 1.37$ & $9.69 \pm 1.17$ & $10.31 \pm 1.29$ & $7.09 \pm 0.74$ & $8.47 \pm 0.94$ & $9.13 \pm 1.24$ \\
\hline
\end{tabular}

Table 3. Halichoerus grypus. Inter-population distance (Dfap) based on fatty acid profiles between groups of female seals. RON: North Rona, MAY: Isle of May

\begin{tabular}{|c|c|c|c|c|}
\hline \multicolumn{5}{|c|}{ (a) Between RON and MAY, within years } \\
\hline Year & & $\mathrm{n}$ & Dfap & $\mathrm{p}$ \\
\hline 1996 & & 57 & 0.225 & $<0.0001$ \\
\hline 1997 & & 56 & 0.109 & $<0.0001$ \\
\hline 1998 & & 53 & 0.115 & $<0.0001$ \\
\hline \multicolumn{5}{|c|}{$\begin{array}{l}\text { (b) Between years within breeding site (number of seals } \\
\text { shown in brackets) }\end{array}$} \\
\hline & \multicolumn{2}{|c|}{ RON } & \multicolumn{2}{|c|}{ MAY } \\
\hline Year & 1996 & 1997 & 1996 & 1997 \\
\hline \multicolumn{5}{|l|}{ Dfap } \\
\hline 1997 & $0.006(48)$ & & $0.084(65)$ & \\
\hline 1998 & $0.018(48)$ & $0.001(50)$ & $0.252(62)$ & $0.166(59)$ \\
\hline \multicolumn{5}{|c|}{ p-value } \\
\hline 1997 & 0.567 & & $<0.0001$ & \\
\hline 1998 & 0.114 & 0.411 & $<0.0001$ & $<0.0001$ \\
\hline
\end{tabular}

These between-year comparisons suggest that the dietary changes over the $3 \mathrm{yr}$ period which occurred at RON were relatively minor, whereas major dietary shifts occurred for the MAY seals.

\section{PCA}

The purpose of PCA is to reduce the large number of original correlated variables to a small number of transformed uncorrelated variables, and it is a good means to graphically represent differences and similarities of all data points. The data were first normalised and standardised as described previously (Walton et al. 2000). For each of the comparisons, in order to ensure that there were never more variables (individual fatty acids) than samples (number of seals), some fatty acids were omitted from the procedure. Those chosen to be omitted were those which contributed least on a percentage basis to the overall pro- 
file. In practice, there was very little difference in the resultant plots regardless of whether these fatty acids were omitted or not.

A comparison between the first and second principal components for RON and MAY for each of the 3 years is shown in Fig. 1. The 1996 comparison (but based on 33 fatty acids) has been described previously in more detail (Walton et al. 2000). In none of the cases was there complete separation between clusters representing seals from the 2 sites. However, the trend was for the majority of samples to form 2 separate clusters, with a degree of overlap, according to geographical location.

Secondly, comparisons were made within each of these sites between the consecutive year periods of 1996 to 1997 and 1997 to 1998 , and also for the 2 yr period 1996 to 1998 , as shown in Fig. 2. Clustering according to year of sampling was evident in all the MAY plots although the effects were clearest for the 1997 to 1998 and 1996 to 1998 comparisons. Separate clusters were not readily apparent for the RON samples in either the 1996 to 1997 or 1996 to 1998 comparisons, but some degree of separation can be seen in the 1997 to 1998 plot.

The inter-annual variation for individual females is shown in Fig. 3. In these PCA plots, the co-ordinates of individual seals for the 2 years being compared are joined by a line. Within each plot (but not between plots because not all factors are equal in determining the principal components), the length of line is an indication of the amount of change. Also, if all seals changed diets in a similar manner, then one would expect the changes to appear in a similar direction. Many, but not all, of the females showed a similar level and direction of change. For all the plots based on the RON seals and the 1996 to 1997 MAY comparison, there was no consistent pattern visible in the 1 or $2 \mathrm{yr}$ changes. However, for the 1997 to 1998 and 1996 to 1998 MAY comparisons, there was an apparent pattern to the observed changes. This may suggest that from 1996 to 1998 there was a substantial dietary shift that affected most of the seals breeding at MAY.

\section{Discriminant analysis}

Discriminant analysis shows how 2 or more predefined groups of individuals may be separated, given measurements of several variables. It provides linear functions of the variables that best separate the cases into the predefined groups and from these, a classification matrix can be produced as shown in Table 4 . Usually results based on this procedure give an overoptimistic estimate of the success of the analysis because the classification rules are evaluated using the same cases used to compute them. To overcome this problem, a jack-knifed classification matrix, which classifies each sample without using that sample to calculate the group means, was produced. The overall accuracy of the classification matrix was $78 \%$ (Wilk's lambda $=0.000, F=7.48, \mathrm{df}=280, \mathrm{p}<0.001$ ). Of the 1993 MAY samples, only 1 was assigned as a RON sample and only 3 out of 73 RON samples were assigned to MAY. Within each of these geographical groupings, assignment to the correct year was performed with greater accuracy for the MAY seals (84 to $97 \%$ ) compared to the RON seals (56 to $74 \%$ ).

\section{Classification tree analysis}

Classification tree analysis uses an algorithm to automatically select the optimal variable for splitting data
1996

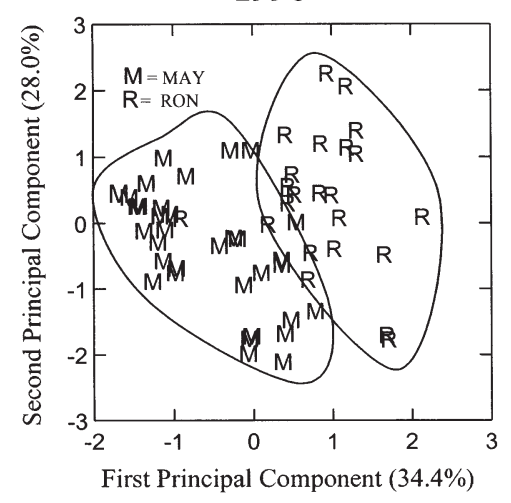

1997

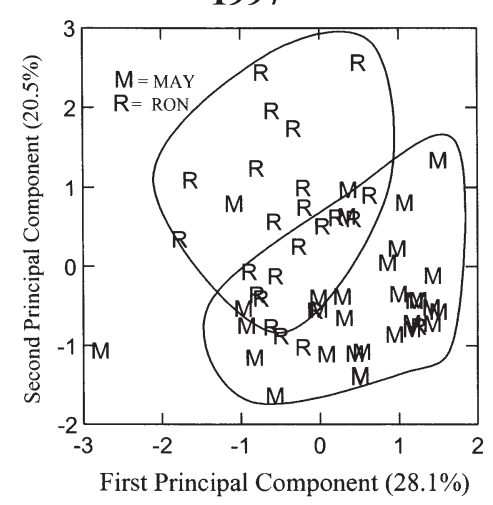

1998

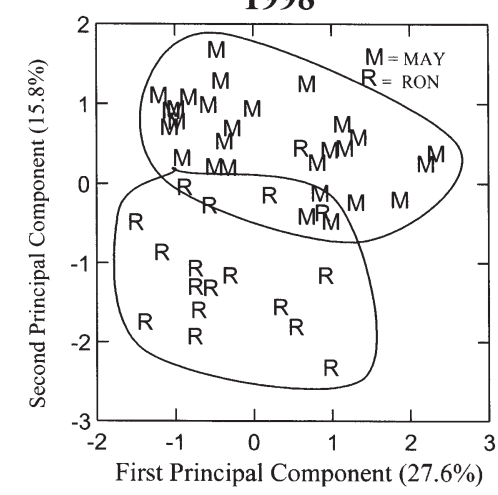

Fig. 1. Halichoerus grypus. Between-site within-year principal component analysis (PCA). Plots of the first 2 components for all seals from the Isle of May (MAY) and North Rona (RON) in the years 1996 to 1998. The percentages given in brackets represent the contribution of the component to the total variance. The arbitrarily drawn lines around the data points are merely illustrative and they have no statistical significance 

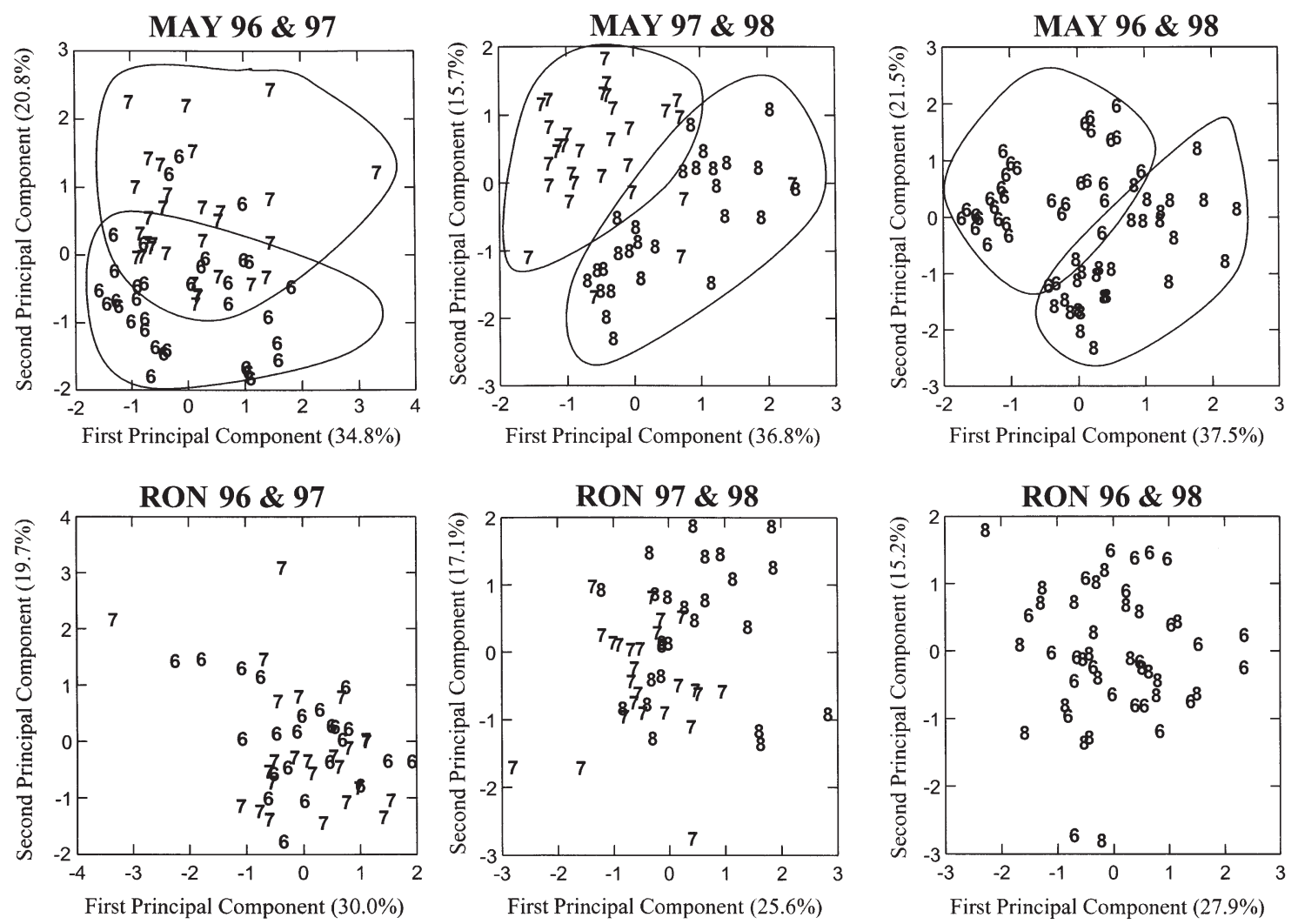

Fig. 2. Halichoerus grypus. Between-year within-site principal component analysis (PCA). Plots of the first 2 components for all seals from the Isle of May (MAY) and North Rona (RON) separately showing between-year comparisons. The percentages given in brackets represent the contribution of the component to the total variance

into 2 groups at nodes. The top node contains the entire sample set. Each remaining node contains a subset of the sample of the node directly above it. The tree is binary because each node splits into 2 subsamples and the splits are determined by whether the levels of a fatty acid are above or below some cutoff value. The classification trees were computed using SYSTAT or SIPINA (Zighed \& Rakotomalala 1996).
There were many 'mis-classifications' in the classification tree (Fig. 4) and it could not resolve RON 1996 from RON 1997. The SIPINA program offers the option of merging nodes and this is sometimes useful to illustrate the classifications more clearly. For instance, merging the 2 lower left nodes (22:6n-3<11.91 and 18:4n-3) produced a node containing 33 MAY 1996 samples (out of a possible 34 ) with only 4 other 'mis-classifications'.

Table 4. Halichoerus grypus. Jack-knifed classification matrix obtained from the discriminant analysis of the fatty acid profiles of seals from North Rona (RON) and the Isle of May (MAY). Wilk's lambda $=0.000, F=7.48, \mathrm{df}=280, \mathrm{p}=<0.001$ )

\begin{tabular}{|c|c|c|c|c|c|c|c|c|}
\hline \multirow[t]{3}{*}{ Actual group } & \multirow{3}{*}{$\begin{array}{c}\text { Actual } \\
\mathrm{n}\end{array}$} & \multicolumn{6}{|c|}{ Assigned group } & \multirow{3}{*}{$\begin{array}{c}\% \\
\text { accuracy }\end{array}$} \\
\hline & & MAY & MAY & MAY & RON & RON & RON & \\
\hline & & 1996 & 1997 & 1998 & 1996 & 1997 & 1998 & \\
\hline MAY 1996 & 34 & 33 & 1 & 0 & 0 & 0 & 0 & 97 \\
\hline MAY 1997 & 31 & 3 & 26 & 2 & 0 & 0 & 0 & 84 \\
\hline MAY 1998 & 28 & 1 & 1 & 25 & 0 & 0 & 1 & 89 \\
\hline RON 1996 & 23 & 1 & 0 & 0 & 17 & 4 & 1 & 74 \\
\hline RON 1997 & 25 & 1 & 0 & 0 & 7 & 14 & 3 & 56 \\
\hline RON 1998 & 25 & 0 & 0 & 1 & 3 & 6 & 15 & 60 \\
\hline Total & 166 & 39 & 28 & 28 & 27 & 27 & 20 & 78 \\
\hline
\end{tabular}


MAY 96 \& 97

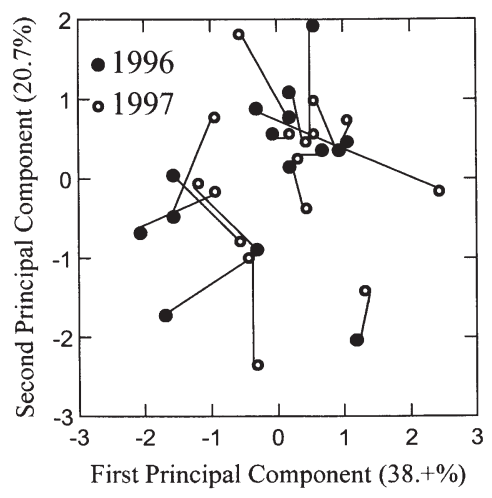

RON 96 \& 97

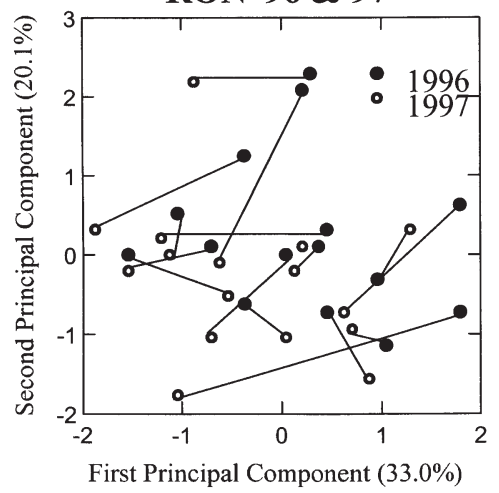

MAY $97 \& 98$

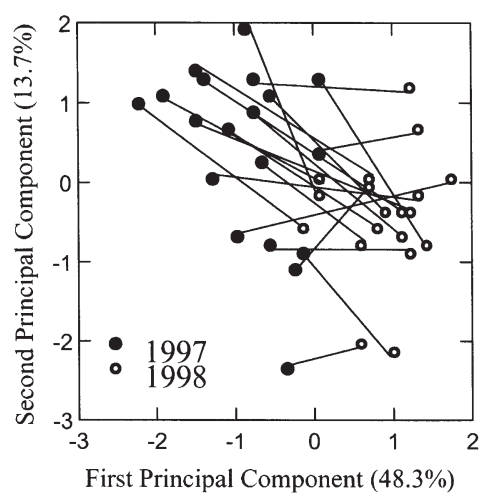

RON 97 \& 98

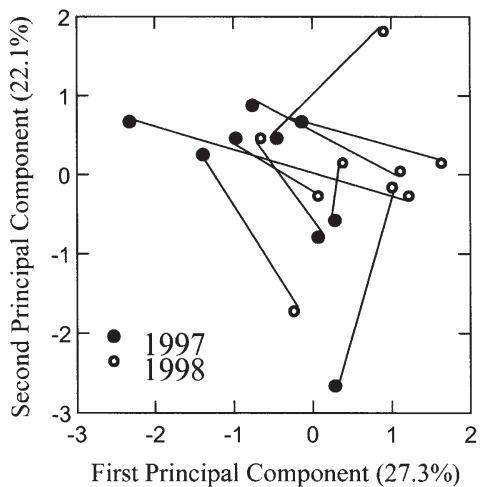

MAY 96 \& 98

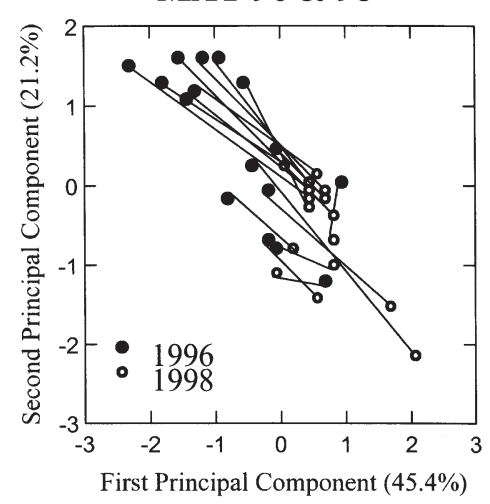

RON 96 \& 98

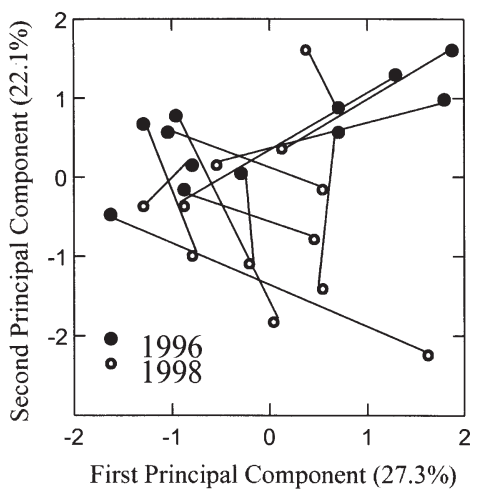

Fig. 3. Halichoerus grypus. Between-year within-site principal component analysis (PCA). Plots of the first 2 components for individual seals sampled in more than 1 yr from the Isle of May (MAY) and North Rona (RON) separately showing between-year comparisons. Each line represents an individual seal. The percentages given in brackets represent the contribution of the component to the total variance

\section{DISCUSSION}

The fatty acid profiles found in the seals from RON and MAY have the typical characteristics of marine oils, in that they contain a wide variety of fatty acids and are rich in polyunsaturated fatty acids especially of the (n-3) series. These major characteristics and overall pattern are basically similar to those in other reports for grey seal blubber (Ackman \& Hooper 1974, Ackman \& Eaton 1988, Schweigert et al. 1990, GrahlNielsen \& Mjaavatten 1991, Fredheim et al. 1995).

The basis for investigating these fatty acid profiles in order to monitor dietary changes is that the composition of fatty acids in depot fat, such as blubber or adipose tissue, is strongly influenced by, but not identical to, the fatty acid composition of the diet. Such a link has been demonstrated in laboratory animals (ValeroGarrido et al. 1990), humans (Plakke et al. 1983, Field \& Clandinin 1984, Tjonneland et al. 1993, Summers et al. 2000), polar bears (Colby et al. 1993) and seals (Iverson 1997a,b). Thus, one would expect that any change detected in blubber fatty acid profiles would reflect changes in the diet. The purpose of the present paper was to measure the extent to which seal fatty acid profiles changed under natural conditions and to use this as an indication of dietary change. In this paper, we are unable to relate the seal fatty acid profiles to specific prey species since we have neither a mathematical model which can achieve this aim nor the required biochemical and prey information. However, we are in the process of collecting the necessary prey information for use when such a model becomes available.

In a previous paper (Walton et al. 2000), we showed that seals from RON and MAY sampled in 1996 could be differentiated based on their fatty acid profiles. The multivariate tests used in the present study indicated that the majority of seals at RON could also be differentiated from those at MAY during the 2 succeeding breeding seasons. In each of these comparisons, there were significant differences between the 2 groups. As well as these differences between sites, differences were also detected between years at each of the 2 sites, but greater changes were seen at MAY than at RON. 


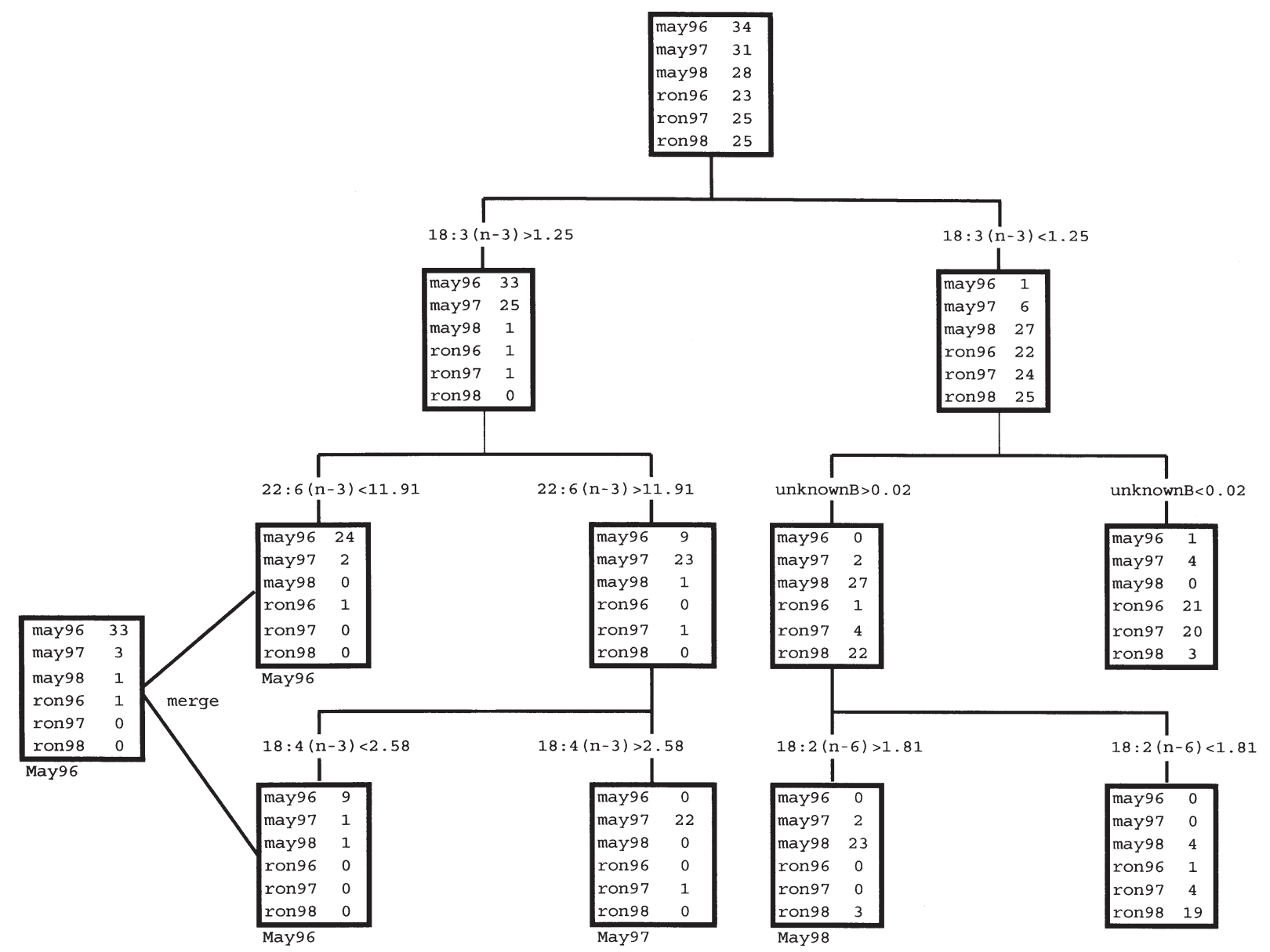

Fig. 4. Plot of a classification tree analysis. The numbers in each box are the number of seals represented, following application of the classification criterion above the box. If 1 group within a box represents at least $75 \%$ of the total samples in a series, then the name of that group is given below the box

At RON, between-year comparisons showed no clear separations using PCA, and the Dfap values were small and statistically non-significant. Discriminant analysis classified the RON profiles into year classes with 56 to $74 \%$ accuracy, although the classification tree analysis could not differentiate between the RON 1996 and 1997 seals. In contrast, at MAY, all the statistical tests showed clearer distinctions between years, and Dfap values were both statistically significant and also much higher than those seen at RON. Discriminant analysis classified the MAY profiles into years with 84 to $97 \%$ accuracy and the classification tree analysis could differentiate all 3 year groups. The most likely explanation to explain this finding is that there are consistent differences in the diets between seals at RON and MAY. Other theoretical but unlikely possibilities exist, such as that seals at the 2 colonies eat the same diet but the profiles of the prey are different. Not only is it unlikely that exactly the same prey choices would have been available at the 2 sites, but Smith et al. (1997) have shown that between-fish species varia- tion is much greater than within-species variations due to location, size etc. Within each site, there were differences in the profiles from year to year. However, these changes were relatively minor at RON but were much greater at MAY, which is indicative of major dietary switches. Some change from year to year is not unexpected since grey seals are known to eat a wide variety of prey species (see below). Therefore, it is highly unlikely that they would eat exactly the same proportions of different species from year to year or even from season to season. Much will depend upon prey availability and it may be that this feature was relatively stable during the study period at RON, but that much greater fluctuations occurred at MAY. The withinanimal changes found between years indicated that there was a lot of individual variation among the seals at RON, but at MAY nearly all seals sampled changed diet in a similar manner. The implication of major dietary shifts for the MAY seals can be related to evidence, described below, available from other sources on their movements and diet. 
Satellite relay data logger (SRDL) telemetry devices have been applied to grey seals, and used to investigate the movements and foraging areas of grey seals from MAY and nearby haul-out sites (McConnell et al. 1999). Apparent foraging areas were mostly localised to areas in the North Sea, mainly within $60 \mathrm{~km}$ of a haul-out site. No significant differences were observed in the distribution of foraging areas from MAY between 1997 and 1998. Thus, most seals tended to feed locally. Hence, in the comparisons of MAY and RON seals, most profiles should, in general, reflect diets of seals feeding in the North Sea and the Atlantic sections of their range, respectively.

The results from faecal analysis of diet at a number of locations (Hammond \& Prime 1990, Bowen \& Harrison 1994, Hammond et al. 1994a,b, Thompson et al. 1996) have shown that grey seals feed on a wide variety of fish prey. For the seals found in Scottish waters, over 30 different prey species have been detected with eleven fish species making up over $90 \%$ of the diet. The major dietary items were sand eels and gadoids (cod, ling and whiting). The diet of seals at RON have not been specifically studied, but for the MAY seals a study was performed by Hall (1999). She analysed 341 grey seal faecal samples (of which 241 contained otoliths) collected at MAY and Abertay Sands (a regular haul-out site for seals which breed on MAY) on a seasonal (3 monthly) basis between 1996 and 1998. The seals in that study and those here are likely to be members of the same colony. The results, which were concurrent with the present study, showed a high proportion of sandeels was present in the diet of grey seals, although there were inter-annual and intraseasonal variations. During the season (3 mo period) prior to blubber sampling at MAY, the estimated \% diet composition was sandeel 48 , cod 33 , whiting 4 , saithe 4 and others 11 for 1996; plaice 55, sandeel 34 and others 11 for 1997; and cod 51, sandeels 16, whiting 15, gadoids 11 and others 7 for 1998. Thus, the significant differences seen in the fatty acid profiles between years is consistent with these marked differences in the diet composition. Several other studies have also detected significant inter-annual changes in the diet of seals. Also using faecal analysis, Tollit \& Thompson (1996) detected significant variations between years in the levels of sandeels, octopus and cod in the diet of harbour seals Phoca vitulina using the Moray Firth area in NE Scotland. Brown et al. (1999) found considerable inter- and intra-annual variability in the fatty acid composition of milk of Antarctic fur seals Arctocephalus gazella, which is related to diet, in the 3 consecutive years from 1991 to 1993. Inter-annual differences in diet composition found in these studies highlight the importance of long-term studies for understanding the dynamics of seal-prey interactions.
Also, if it does become feasible to determine prey items from blubber fatty acid profiles, it would be interesting to reanalyse these results, especially the within-animal changes, and compare the results with those found from faecal analysis.

Acknowledgements. We are grateful to numerous colleagues, students and others who helped in the collection of material for this study. We would also like to thank NERC and the European Commission for their contribution to the funding of the project.

\section{LITERATURE CITED}

Ackman RG, Eaton CA (1988) n-3 docosapentaenoic acid in blubber of dam and pup grey seals: implications for the Inuit diet and for human health. Can J Zool 66:2428-2431

Ackman RG, Hooper SN (1974) Long chain monoethylenic and other fatty acids in heart liver and blubber lipids of two harbour seals and one grey seal. J Fish Res Board Can 31:333-341

Ackman RG, Epstein S, Eaton CA (1971) Differences in the fatty acid composition of blubber fats from NW Atlantic fin whales and harp seals. Comp Biochem Physiol 40B: 683-697

Bowen WD, Harrison GD (1994) Offshore diet of grey seals (Halichoerus grypus) near Sable Island, Canada. Mar Ecol Prog Ser 112:1-11

Brown DJ, Boyd IL, Cripps GC, Butler PJ (1999) Fatty acid signature analysis from the milk of Antarctic fur seals and Southern elephant seals from South Georgia: implications for diet determination. Mar Ecol Prog Ser 187:251-263

Castell JD, Boston LD, Miller RJ, Kenchington T (1995) The potential identification of the geographic origin of lobster eggs from various wild stocks based on fatty acid composition. Can J Fish Aquat Sci 52:1135-1140

Christie WW (1989) Gas chromatography and lipids: a practical guide. Oily Press, Dundee

Colby RH, Mattacks CA, Pond CM (1993) The gross anatomy cellular structure and fatty acid composition of adipose tissue in captive polar bears. Zoo Biol 12:267-275

Excoffier L, Smouse PE, Quattro JM (1992) Analysis of molecular variance inferred from metric distances among DNA haplotypes: application to human mitochondrial DNA restriction data. Genetics 131:479-491

Field CJ, Clandinin MT (1984) Modulation of adipose tissue fat composition by diet: a review. Nutr Res 4:743-755

Folch J, Lees M, Sloane-Stanley GH (1957) A simple method for the isolation and purification of total lipids from animal tissues. J Biol Chem 226:497-509

Fredheim B, Holen S, Ugland KI, Grahl-Nielsen O (1995) Fatty acids composition in blubber heart and brain from phocid seals. In: Blix AS, Walloe L, Ultang O (eds) Whales, seals, fish and man. Elsevier Science, Amsterdam, p 153-168

Grahl-Nielsen O (1999) Comment: fatty acid signatures and classification trees: new tools for investigating the foraging ecology of seals. Can J Fish Aquat Sci 56:2219-2223

Grahl-Nielsen O, Mjaavatten O (1991) Dietary influence on fatty acid composition of blubber fat of seals as determined by biopsy: a multivariate approach. Mar Biol 110: $59-64$

Grahl-Nielsen O, Mjaavatten O, Tvedt E (1993) Distinguishing between different populations of harp seal by 
chemometry of the fatty acid profiles in the jaw bone. Can J Fish Aquat Sci 50:1400-1404

Hall AJ (1999) The diet of grey seals using faecal analysis. Final Report of European Commission Project 95/78 of DGXIV. Effects of large scale industrial fisheries on nontarget species (ELIFONTS). St Andrews University, St Andrews, p 6.5-6.51

Hammond PS, Prime JH (1990) The diet of British grey seals. Can Bull Fish Aquat Sci 222:243-254

Hammond PS, Hall AJ, Prime JH (1994a) The diet of grey seals around Orkney and other island and mainland sites in north-eastern Scotland. J Appl Ecol 31:340-350

Hammond PS, Hall AJ, Prime JH (1994b) The diet of grey seals in the Inner and Outer Hebrides. J Appl Ecol 31: $737-746$

Harwood J (1987) Competition between seals and fisheries. Sci Prog 71:429-437

Harwood J, Croxall JP (1988) The assessment of competition between seals and commercial fisheries in the North Sea and the Antarctic. Mar Mamm Sci 4:13-33

Iverson SJ (1993) Milk secretion in marine mammals in relation to foraging: can milk fatty acids predict diet? Symp Zool Soc Lond 66:263-291

Iverson SJ, Arnould JPY, Boyd IL (1997a ) Milk fatty acid signatures indicate both major and minor shifts in the diet of lactating Antarctic seals. Can J Zool 75:188-197

Iverson SJ, Frost KJ, Lowry LF (1997b) Fatty acid signatures reveal fine scale structure of foraging distribution of harbour seals and their prey in Prince William Sound Alaska. Mar Ecol Prog Ser 151:255-271

Jobling M (1987) Marine mammal faeces samples as indicators of prey importance-a source of error in bioenergetics models. Sarsia 72:255-260

Jobling M, Breiby A (1986) The use and abuse of fish otoliths in studies of feeding habits of marine piscivores. Sarsia 71 : 265-274

Kakela R, Hyvarinen H, Vainiotalo P (1993) Fatty acid composition in liver and blubber of the Saimaa ringed seal compared with that of the ringed seal and grey seal from the Baltic. Comp Biochem Physiol 105B:553-565

Kirsch PE, Iverson SJ, Bowen WD (2000) Effect of a low-fat diet on body composition and blubber fatty acids of captive juvenile harp seals. Physiol Biochem Zool 73:45-59

McConnell BJ, Fedak MA, Lovell P, Hammond PS (1999) Movements and foraging areas of grey seals in the North Sea. J Appl Ecol 36:573-590

Palumbi S, Martin A, Kessing B, McMillan M (1991) Detecting population structure using mitochondrial DNA. In: Hoelzel A (ed) Genetic ecology of whales and dolphins, Vol 13. Int Whaling Comm Rep Spec Iss, Cambridge, p 271-278

Pierce GJ, Boyle PR, Thompson PM (1990) Diet selection by seals In: Barnes M, Gibson RN (eds) Trophic relationships in the marine environment. Proc 24th Eur Mar Biol Symp. Aberdeen University Press, Aberdeen, p 222-238

Pierce GJ, Miller A, Thompson PM, Hislop JRG (1991) Prey remains in grey seal (Halichoerus grypus) faeces from the Moray Firth, north-east Scotland. J Zool Lond 224: 337-341

Pierce GJ, Boyle PR, Watt J, Grisley M (1993) Recent advance in diet analysis of marine mammals. Symp Zool Soc Lond 66:241-261

Plakke T, Berkel J, Beynen AC, Hermus RJJ, Katan MB (1983) Relationship between the fatty acid composition of diet

Editorial responsibility: Otto Kinne (Editor),

Oldendorf/Luhe, Germany and that of subcutaneous fat in individual human subjects. Hum Nutr Appl Nutr 37A:365-372

Pomeroy PP, Fedak MA, Rothery P, Anderson SS (1999) Consequences of maternal size for reproductive expenditure on pupping success of grey seals at North Rona, Scotland. Anim Ecol 68:235-253

Pond CM, Mattacks CA, Gilmour I, Johnston MA, Pillinger CT, Prestrud P (1995) Chemical and carbon isotopic composition of fatty acids in adipose tissue as indicators of dietary history in wild arctic foxes on Svalbard. J Zool 236: 611-623

Prime JH, Hammond PS (1990) The diet of grey seals from the south-western North Sea assessed from analyses of hard parts found in faeces. J Appl Ecol 27:435-447

Rice WR (1989) Analysing tables of statistical tests. Evolution 43:223-225

Schneider S, Kueffer JM, Roessli D, Excoffier L (1996) Manuel Arlequin: a software for population genetic data analysis, Version 1.1. University of Geneva

Schweigert FJ, Stobo WT, Zucker H (1990) Vitamin E and fatty acids in the grey seal. J Comp Physiol B 159:649-654

Smith RJ, Hobson KA, Koopman HN, Lavigne DM (1996) Distinguishing between populations of fresh-water and saltwater harbour seals using stable-isotope ratios and fatty acids profiles. Can J Fish Aquat Sci 53:272-279

Smith SJ, Iverson SJ, Bowen WD (1997) Fatty acid signatures and classification trees: new tools for investigating the foraging ecology of seals. Can J Fish Aquat Sci 54:1377-1386

Smith SJ, Iverson SJ, Bowen WD (1999) Reply: fatty acid signatures and classification trees: new tools for investigating the foraging ecology of seals. Can J Fish Aquat Sci 56: $2224-2226$

Summers LKM, Barnes SC, Fielding BA, Beysen C, Ilic C, Humphreys AM, Frayn KN (2000) Uptake of individual fatty acids into adipose tissue in relation to their presence in the diet. Am J Clin Nutr 71:1470-1477

Thompson PM, McConnell BJ, Tollit DJ, Mackay A, Hunter C, Racey PA (1996) Comparative distribution, movements and diet of harbour and grey seals from the Moray Firth, N.E. Scotland. J Appl Ecol 33:1572-1584

Tjonnenland A, Overvad K, Thorling E, Ewertz M (1993) Adipose tissue fatty acids as biomarkers of dietary exposure in Danish men and women. Am J Clin Nutr 57:629-633

Tollit DJ, Thompson PM (1996) Seasonal and between year variations in the diet of Harbour seals in the Moray Firth, Scotland. Can J Zool 74:1110-1121

Valero-Garrido D, Lopez-Frias M, Llopis J, Lopez-Jurado M (1990) Influence of dietary fats on the lipid composition of perineal adipose tissue of rats. Ann Nutr Metab 34: $327-332$

Walton MJ, Henderson RJ, Pomeroy PP (2000) Use of blubber fatty acid profiles to distinguish dietary differences between grey seals from two UK breeding colonies. Mar Ecol Prog Ser 193:201-208

West GC, Burns JJ, Modafferi M (1979) Fatty acid composition of blubber from 4 species of Bering Sea phocid seals. Can J Zool 57:1289-1295

Wright S (1978) Evolution and the genetics of populations, Vol 4. Variability within and among natural populations. University of Chicago Press, Chicago, IL

Zighed A, Rakotomalala R (1996) SIPINA for Windows: user's guide. A tool for knowledge discovery in databases. Laboratoire ERIC, Université Lyon 2, Lyon. Free software available at eric.univ-lyon2.fr/ ricco/SipinaEducational.zip

Submitted: April 11, 2002; Accepted: September 20, 2002

Proofs received from author(s): January 24, 2003 